\title{
The Influence of Strata on the Nutrient Recycling within a Tropical Certified Organic Coffee Production System
}

\author{
F. Mamani-Pati, ${ }^{1,2}$ D. E. Clay, ${ }^{1}$ S. A. Clay, ${ }^{1}$ H. Smeltekop, ${ }^{2}$ and M. A. Yujra-Callata ${ }^{2}$ \\ ${ }^{1}$ South Dakota State University, Brookings, SD 57007, USA \\ ${ }^{2}$ Bolivian Catholic University "San Pablo", UAC-Carmen Pampa, Coroico, La Paz, Bolivia
}

Correspondence should be addressed to D. E. Clay, david.clay@sdstate.edu

Received 20 February 2012; Accepted 29 March 2012

Academic Editors: M. P. F. Fontes, B. Trognitz, and X. Xu

Copyright (C) 2012 F. Mamani-Pati et al. This is an open access article distributed under the Creative Commons Attribution License, which permits unrestricted use, distribution, and reproduction in any medium, provided the original work is properly cited.

\begin{abstract}
In tropical Bolivia coffee plantations, the plant community can be separated into high (trees), middle (coffee), and low (weed) strata. Understanding the importance of each stratum is critical for improving the sustainability of the system. The objective of this study was to determine the importance of strata on nutrient recycling. Litter falls from the upper and middle strata were collected monthly using cone-shaped traps and divided by species into leaves, branches, flowers, and fruits. Dry biomass additions to the soil from high and middle strata totaled $12,655 \mathrm{~kg}$ (ha yr) $)^{-1}$ annually. About $76 \%$ of the biomass was provided by plants of the genus Inga (I. adenophylla and I. oerstediana). The middle stratum (Coffea arabica L.) provided $24 \%$ litterfall biomass. This stratum also produced $1,800 \mathrm{~kg}$ coffee bean per ha (12\% moisture) which sold for $\$ 2.94 \mathrm{~kg}^{-1}$. In the lower stratum, Oxalis mollissima returned $36 \mathrm{~kg} \mathrm{~N}$ ha $^{-1}$, while Solanum nodiflorum returned $49 \mathrm{~kg} \mathrm{~K} \mathrm{ha}^{-1}$, and Urtica sp. returned $18 \mathrm{~kg} \mathrm{Ca} \mathrm{ha}^{-1}$. The nutrients recycled through plants in three strata exceeded the amount of nutrients removed in green coffee beans.
\end{abstract}

\section{Introduction}

Organic coffee production is an important industry in Brazil, Colombia, Mexico, and Bolivia. In these countries, the best quality coffee is produced at altitudes ranging from 1,200 to 2,000 meters above sea level with an annual temperature ranging from 17 to $23^{\circ} \mathrm{C}$ and between 1,600 and $2,800 \mathrm{~mm} \mathrm{yr}^{-1}$ of precipitation $[1,2]$. The soil must

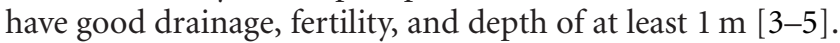
The long-term resilience of this system requires that more nutrients be returned to the soil than are removed in the harvested fruit [6].

In Bolivia, the plant communities on the plantation can be separated into high, medium, and low strata. In the high stratum, two trees commonly found in coffee plantations are Inga adenophylla and Inga oerstediana. These trees (1) provide shade [7-12] that improves coffee quality; (2) recycle nutrients from deeper soil layers [13-17]; (3) protect the coffee bush from extreme wind and rain and excessive light; (4) help regulate climate variability $[18,19]$; (5) help stabilize the soil, reduce soil erosion and bulk densities, and increase water infiltration [20-22]; (6) as native leguminous plants provide $\mathrm{N}$ through symbiotic $\mathrm{N}_{2}$-fixation [23-35]. The nutrients returned to soil by the higher strata can be substantial. Babbar and Zak [36] reported that the total $\mathrm{N}$ contribution was $145 \mathrm{~kg} \mathrm{~N}$ (ha year) ${ }^{-1}$, while Aranguren et al. [37] and Bornemisza [38] had slightly lower estimates, with contributions ranging from $86 \mathrm{~kg} \mathrm{~N}$ (ha year) ${ }^{-1}$ to $100 \mathrm{~kg} \mathrm{~N}$ (ha year) ${ }^{-1}$.

In the middle stratum, coffee is grown and ripe fruits are harvested and processed, resulting in a green coffee "bean" that is commercialized. Branches and leaves from the coffee plant fall and return nutrients to the soil. The amount of $\mathrm{N}$ contained in these leaves can range from 28 to $35 \mathrm{~kg}$ $\mathrm{N}$ (ha year) ${ }^{-1}[16,37,39]$. Medina et al. [40] had similar results and reported that the leaves and branches from the coffee plant returned $41,3,10,39$, and $11 \mathrm{~kg}$ (ha year) ${ }^{-1}$ of $\mathrm{N}, \mathrm{P}, \mathrm{K}, \mathrm{Ca}$, and $\mathrm{Mg}$, respectively, to the soil.

In the lower stratum the typical plant community structure consists of Oxalis mollissima, Urtica sp., Commelina cf. virginica L., and Solanum nodiflorum. In organic systems, 


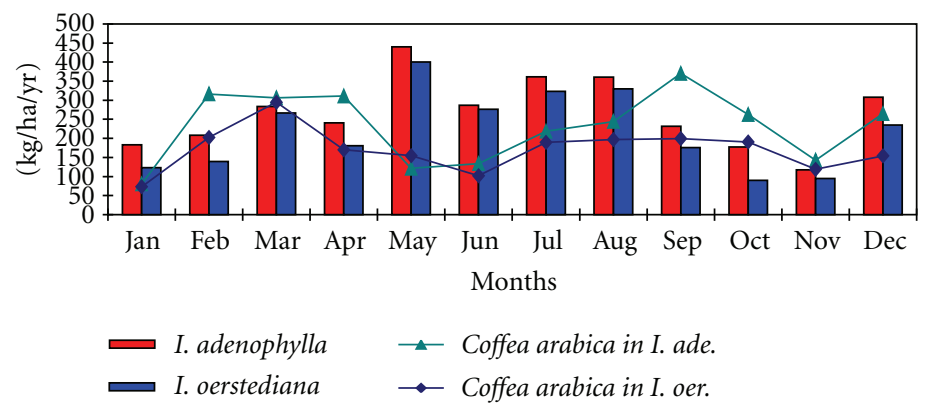

FIGURE 1: Interaction of species with months for leaf falls over one year (interaction month $x$ type of litter: $P=0.0267$ ).

these plants are generally controlled through mechanical techniques. Benefits of these and other plants include reduced runoff and erosion, increased carbon sequestration, $\mathrm{N}$ fixation, and a habitat for beneficial insects [41-47]. The sustainability of organic coffee production systems requires that the interconnectivity of individual components be understood. The objective of this study was to determine the importance of strata on nutrient recycling in a certified mature tropical organic coffee plantation in Bolivia.

\section{Materials and Methods}

A field experiment was conducted in the Yungas Valley of Carmen Pampa located on the eastern slopes of the Andes. The latitude, longitude, and elevation at the site are $16^{\circ} 15^{\prime}$ $31.17^{\prime \prime} \mathrm{S}, 67^{\circ} 41^{\prime} 32.77^{\prime \prime} \mathrm{W}$, and 1851 m.a.s.l. The region is characterized by mountain ranges with wide slopes and long valleys formed from sedimentary and metamorphic rock. In this region, elevation can range from 400 to $3500 \mathrm{~m}$.

Soils at the research site were Humic Dystrudepts [4850]. These soils have $\mathrm{pH}$ values that range from 4.3 to 4.5 $[49,51]$, have a loamy soil texture, a subangular, blocky structure, high organic matter levels $\left(68 \mathrm{~g} \mathrm{~kg}^{-1}\right)$, moderate to high permeability, high Al content $\left(2.5-3.8 \mathrm{cmol}_{\mathrm{c}} \mathrm{kg}^{-1}\right)$, and low cation exchange capacity $\left(6.5-9.5 \mathrm{cmol}_{\mathrm{c}} \mathrm{kg}^{-1}\right)$.

The upper stratum is composed of two tree species, $I$. adenophylla and I. oerstediana. These trees were planted over 40 years ago. The spacing between trees is approximately $4 \mathrm{~m}$. The medium stratum contained coffee (Coffea arabica L.) $>10$ years old. Litterfall samples from the upper and middle strata were collected with cone-shaped traps that were $1 \mathrm{~m}$ long by $1 \mathrm{~m}$ wide by $0.30 \mathrm{~m}$ tall $[52,53]$. The traps were placed at random at a distance of 2 to $3 \mathrm{~m}$ from the trees and fixed at $10 \mathrm{~cm}$ above the ground. The traps are supported by four stakes at the corners. Litterfall was collected monthly and divided into species and vegetative parts (leaves, branches, flowers, and fruits of the upper and middle strata). The low stratum consisted of weeds that were less than $50 \mathrm{~cm}$ tall. Plant samples from the lower stratum were collected randomly three times in a year using a $75 \mathrm{~cm} \times$ $75 \mathrm{~cm}$ square frame and divided into species.

Collected litter fall samples were dried at $70^{\circ} \mathrm{C}$, ground, and analyzed to determine $\mathrm{N}, \mathrm{P}, \mathrm{K}, \mathrm{Ca}, \mathrm{Mg}$, and $\mathrm{S}$ content. Total nitrogen was determined by the Kjeldahl digestion method followed by distillation. After ashing, phosphorus (P) was determined by the molybdenum blue colorimetric method, and potassium $(\mathrm{K})$, calcium $(\mathrm{Ca})$, and magnesium $(\mathrm{Mg})$ were determined using an atomic absorption spectrophotometer.

To determine the diversity of soil macrofauna, aboveground litter samples were collected from the soil surface at ten random sites using a $20 \mathrm{~cm} \times 20 \mathrm{~cm}$ square frame. Macrofauna were extracted from approximately $100 \mathrm{~g}$ of this material using a Berlese funnel [54-56] for a period of five days. Individual macrofauna were identified and classified using comparison and taxonomy keys. Individuals of the same order were separated, quantified, and stored in ethanol.

Within the upper and middle strata each measurement was replicated at least 5 times. The amount of biomass and nutrients returned to the soil from major plant types within strata were determined. Litterfall was measured monthly from January to December of 2006. The importance of the 2 tree species (Inga adenophylla and Inga oerstediana) within the upper stratum was determined using a mixed model methodology in a two-stage approach (Statistical Analysis System version 9.2 for Windows). The first stage attempted to select an appropriate covariance model by the criterion with the minimum value of Akaike Information Criterion (AIC), the finite-population corrected AIC (AICC), and Schwarz's Bayesian Information Criterion (BIC), and the second stage assessed treatment and time effects using generalized least squares with the estimated covariance [57-59].

\section{Results and Discussion}

3.1. Biomass from the Upper and Middle Strata. Leaves returned to the soil from the upper and middle strata are a mechanism for returning nutrients to the soil. Leaf fall data showed a heterogeneous behavior during the year of collection, correlating with the phenological growth stage of each species. The high stratum (I. adenophylla and I. oerstediana) provided more total biomass in May, June, July, and August than the middle stratum, while in February, September, and October the middle stratum contributed more leaves than the upper stratum (Figure 1). These unexpectedly high contributions were most likely associated with the senescence due to nutritional deficiencies [60]. Leaf litterfall may also be affected by wind and rain [61], excess 
TABLE 1: Annual litter and nutrient additions from different components of litterfall in the coffee agroecosystems.

\begin{tabular}{|c|c|c|c|c|c|c|c|c|c|}
\hline & \multirow{2}{*}{ Species } & & \multicolumn{7}{|c|}{ Inputs from litterfall (kg (ha yr) $)^{-1}$, dry weight) } \\
\hline & & & Litterfall & $\mathrm{N}$ & $\mathrm{P}$ & $\mathrm{K}$ & $\mathrm{Ca}$ & $\mathrm{Mg}$ & $\mathrm{S}$ \\
\hline \multirow{11}{*}{ Upper stratum } & \multicolumn{9}{|l|}{ Inga spp. } \\
\hline & \multirow{5}{*}{ I. adenophylla } & Leaves & 3199 & 65.26 & 4.79 & 10.09 & 15.36 & 3.20 & 4.80 \\
\hline & & Branches & 814 & 6.43 & 0.47 & 1.62 & 4.31 & 0.49 & 0.81 \\
\hline & & Flowers & 1593 & 34.41 & 3.57 & 7.01 & 10.67 & 2.07 & 3.19 \\
\hline & & Fruits & 204 & 0.12 & 0.29 & 1.85 & 0.86 & 0.18 & 0.43 \\
\hline & & Total & 5810 & 106.22 & 9.11 & 20.56 & 31.20 & 5.94 & 9.23 \\
\hline & \multirow{5}{*}{ I. oerstediana } & Leaves & 2627 & 54.12 & 1.85 & 7.63 & 19.18 & 2.36 & 4.99 \\
\hline & & Branches & 417 & 3.04 & 0.29 & 0.80 & 2.84 & 0.25 & 0.38 \\
\hline & & Flowers & 675 & nd & nd & nd & nd & nd & nd \\
\hline & & Fruits & 94 & 1.95 & 0.12 & 1.25 & 0.57 & 0.12 & 0.17 \\
\hline & & Total & 3813 & 59.11 & 2.26 & 9.68 & 22.59 & 2.74 & 5.54 \\
\hline \multirow{5}{*}{ Middle stratum } & \multirow{5}{*}{ Coffea arabica } & Leaves & 2210 & 54.15 & 3.60 & 27.51 & 40.22 & 4.64 & 5.97 \\
\hline & & Branches & 29 & 0.27 & 0.03 & 0.04 & 0.18 & 0.04 & 0.03 \\
\hline & & Flowers & nd & nd & nd & nd & nd & nd & nd \\
\hline & & Fruits & 793 & 0.87 & 1.08 & 9.08 & 1.67 & 0.95 & 1.27 \\
\hline & & Total & 3032 & 55.29 & 4.71 & 36.64 & 42.06 & 5.63 & 7.26 \\
\hline \multirow{7}{*}{ Lower stratum } & \multicolumn{9}{|l|}{ Weed } \\
\hline & Commelina cf. virginica L. & & 1136 & 35.22 & 4.65 & 46.48 & 8.75 & 3.07 & 1.48 \\
\hline & Urtica sp. & & 1028 & 32.07 & 3.94 & 25.60 & 18 & 2.78 & 2.26 \\
\hline & Solanum nodiflorum Jacq. & & 1476 & 43.25 & 4.68 & 48.88 & 14.17 & 2.36 & 4.87 \\
\hline & Oxalis mollissima R. Knuth & & 1272 & 36.12 & 4.03 & 43.39 & 10.56 & 3.18 & 2.16 \\
\hline & Drymaria cordata L. & & 1224 & 30.23 & 4.15 & 44.40 & 5.88 & 2.94 & 5.75 \\
\hline & & Total & 6136 & 176.89 & 21.44 & 208.75 & 57.34 & 14.32 & 16.52 \\
\hline
\end{tabular}

humidity, and foliar diseases caused by pathogenic fungi (Mycena citricolor, Berk and Curt) [62-65]. American leaf spot is one of the most serious fungal diseases in coffee production across Latin America [66, 67], causing premature defoliation [67-69].

Over the year, Inga adenophylla $\left(3199 \mathrm{~kg}(\mathrm{ha} \mathrm{yr})^{-1}\right)$ contributed more biomass from leaves to the soil than Inga oerstediana $\left(2627 \mathrm{~kg}(\mathrm{ha} \mathrm{yr})^{-1}\right)$. Both trees contributed more total biomass than coffee $\left(2210 \mathrm{~kg}(\text { ha yr })^{-1}\right)$, although coffee leaf loss under I. adenophylla was slightly greater in September. Fallen leaves are important to the cropping system as they cover the soil and thereby reduce erosion, recycle nutrients, and provide habitat for beneficial organisms [70, 71]. The litterfall becomes an important source of organic matter and activates the biogeochemical cycle [72-77]. The trees allow for more efficient capture of solar energy and favor the adsorption, retention, or capture of carbon and nitrogen above and below the ground [78-80].

3.2. Nutrient Return in Biomass from Upper and Middle Strata. The annual input of leaf litterfall returned to the soil was $8,036 \mathrm{~kg}$ dry weight (ha yr $)^{-1}$. Of this, $28 \%$ was from coffee, which contained $54,4,28,40,5$, and $6 \mathrm{~kg}\left(\right.$ ha yr) ${ }^{-1}$ of $\mathrm{N}, \mathrm{P}$, $\mathrm{K}, \mathrm{Ca}, \mathrm{Mg}$, and $\mathrm{S}$. The $5,826 \mathrm{~kg} \mathrm{ha}^{-1}$ from the upper stratum contained $119,7,18,35,6$, and $10 \mathrm{~kg}(\mathrm{hayr})^{-1}$ of $\mathrm{N}, \mathrm{P}, \mathrm{K}$, $\mathrm{Ca}, \mathrm{Mg}$, and $\mathrm{S}$, respectively (Table 1 ). The contributions from the upper stratum were higher than those reported by OIRSA [81], Sánchez et al. [82], and lower than those by Alpizar et al. [83].

In organic coffee production it is critical to minimize $\mathrm{N}$ deficiencies. $\mathrm{N}$ deficiencies can cause yellowing in coffee leaves making the plant more susceptible to diseases such as Cercospora leaf spot and cherry/berry blotch $[67,84]$, which impacts quality and caffeine content [85-89]. Shade trees can reduce stress by providing $\mathrm{N}$ through $\mathrm{N}$-fixation and by reducing $\mathrm{N}$ leaching losses [25, 90-95]. A comparison between the $\mathrm{N}$ content of the organically produced green beans and the well-fertilized production fields of this study suggests that $\mathrm{N}$ was above the critical level.

For long-term stability, the $\mathrm{N}$ removed by the crop must be less than the $\mathrm{N}$ returned to the soil. Assessing the nutrient balance is an important step in determining the long-term resilience of the system [96-98]. An important part of organic coffee systems is the shade trees. They take in $\mathrm{N}$ from the atmosphere and contribute this $\mathrm{N}$ to coffee through litterfall and subsequent decomposition [36, 99-103].

Branches from the upper and middle stratum contributed $1,260 \mathrm{~kg}(\mathrm{hayr})^{-1}$ of biomass to the soil. Of this, $98 \%$ was from Inga spp. and 2\% was from coffee (Table 1). The annual nutrient return through branch litterfall in the upper stratum (I. adenophylla and I. oerstediana) was 9, 1, 2, 7, 0.7, and $1.2 \mathrm{~kg}$ (ha yr) $^{-1}$ of $\mathrm{N}, \mathrm{P}, \mathrm{K}, \mathrm{Ca}, \mathrm{Mg}$, and $\mathrm{S}$, 
respectively. Branches from coffee provided $0.27,0.03,0.04$, $0.18,0.04$, and $0.03 \mathrm{~kg}$ (ha yr) ${ }^{-1}$ of $\mathrm{N}, \mathrm{P}, \mathrm{K}, \mathrm{Ca}, \mathrm{Mg}$, and $\mathrm{S}$, respectively.

Flowers made a relatively minor contribution to the soil. Although the two trees in the upper stratum flowered from June to December, the maximum contribution occurred in September. Flowers returned $34,4,7,11,2$, and $3 \mathrm{~kg}(\text { ha yr })^{-1}$ of $\mathrm{N}, \mathrm{P}, \mathrm{K}, \mathrm{Ca}, \mathrm{Mg}$, and $\mathrm{S}$, respectively (Table 1). Nutrients returned to the soil from the coffee flowers in the middle stratum were insignificant.

Trees in the upper stratum and coffee in the middle stratum also returned nutrients to the soil in the form of fruit litterfall. The combined contribution from genus Inga and Coffea arabica was $1,091 \mathrm{~kg}$ (ha yr) $)^{-1}$ dry biomass (Table 1 ). The total fruit biomass collected from the upper stratum was $298 \mathrm{~kg}$ (ha yr) $)^{-1}$. Fruit provided 2.07, 0.41, 3, 1.43, 0.30, and $0.6 \mathrm{~kg} \mathrm{ha}^{-1}$ of $\mathrm{N}, \mathrm{P}, \mathrm{K}, \mathrm{Ca}, \mathrm{Mg}$, and $\mathrm{S}$, respectively. In the middle stratum, the contribution of coffee fruit litter was $793 \mathrm{~kg}$ (ha yr) $)^{-1}$. Coffee fruit litter contributed $0.87,1.08$, 9, 2, 0.95, and $1.27 \mathrm{~kg} \mathrm{ha}^{-1}$ of $\mathrm{N}, \mathrm{P}, \mathrm{K}, \mathrm{Ca}, \mathrm{Mg}$, and $\mathrm{S}$, respectively.

3.3. Nutrient Removal in Harvested Coffee Fruit. The harvested coffee cherry was $1,800 \mathrm{Mg} \mathrm{ha}^{-1}$. Nutrients removed in whole fruit were $57,12,122,22,13$, and $17 \mathrm{~kg}$ (ha yr) ${ }^{-1}$ of $\mathrm{N}, \mathrm{P}, \mathrm{K}, \mathrm{Ca}, \mathrm{Mg}$, and $\mathrm{S}$, respectively. Skin, pulp, and parchment were not returned to the field. Based on these values the $\mathrm{N}$ concentration in the harvested green beans was $31.7 \mathrm{~kg}(1,000 \mathrm{~kg} \text { green beans })^{-1}$. This concentration is similar to the values reported for well-fertilized systems $[104,105]$, which suggests that the system is above the critical level.

Chaves and Molina [106] reported that, in Costa Rica, a yield of $2,480 \mathrm{~kg} \mathrm{ha}^{-1}$ of parchment coffee can contain $242 \mathrm{~kg}$ $\mathrm{N}$. Other studies showed that nutrient removal in whole fruit (Coffea arabica) was 35, 3, 54, 5, 10, and $3 \mathrm{~kg}(1,000 \mathrm{~kg}$ green beans) $)^{-1}$ of $\mathrm{N}, \mathrm{P}, \mathrm{K}, \mathrm{Mg}, \mathrm{Ca}$, and S $[39,104,107]$. Romero-Alvarado et al. [108] indicated that between 20 and $80 \%$ of a plant's $\mathrm{N}$ requirement can be supplied through the mineralization of soil organic matter.

3.4. Biomass and Nutrient Returned in the Lower Stratum. The dominant weeds in the lower stratum were Solanum nodiflorum Jacq., Commelina cf. virginica L., Oxalis mollissima R. Knuth, Urtica sp., and Drymaria cordata L. (Table 1). These weeds returned $6,136 \mathrm{~kg}$ (hayr) ${ }^{-1}$ of dry biomass. The contribution of biomass by weeds in the lower stratum was quite variable. The nutrients returned by the weeds in the lower stratum were $177,21,209,57,14$, and $17 \mathrm{~kg}$ (hayr) $^{-1}$ of $\mathrm{N}, \mathrm{P}, \mathrm{K}, \mathrm{Ca}, \mathrm{Mg}$ and $\mathrm{S}$, respectively. The nutrients contained in the lower stratum were returned to soil following mechanical weed control that occurred at the beginning of the rainy season (November), harvest period, and prior to flowering.

3.5. Edaphic Mesofaunal Diversity. The lower strata also contained many insects that assisted in the degradation of plant residues and maintenance of soil quality [109-113].

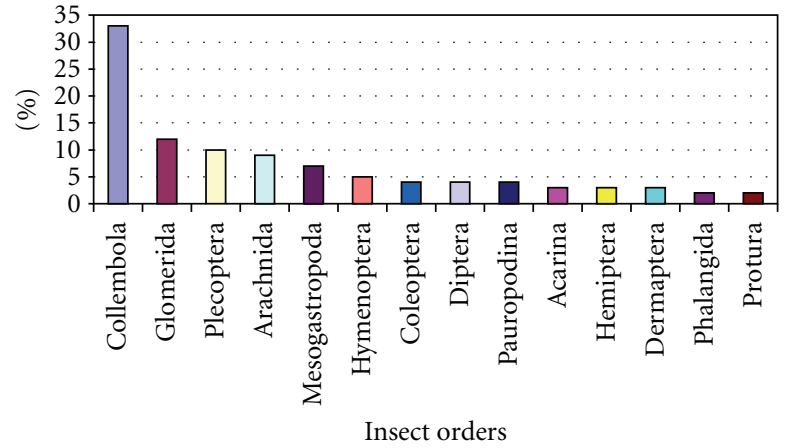

FIGURE 2: Soil mesofauna in the shaded coffee agro-forest system.

These mesofaunal groups were extremely diverse. The largest group, which was $37 \%$ of the total, included the orders Glomerida, Plecoptera, Arachnida, and Mesogastropoda.

The second largest group, which represented 33\% of the total, were Collembola (Figure 2). The least prevalent orders were Hymenoptera, Coleoptera, Diptera, Pauropodina, Acarina, Hemiptera, Dermaptera, Phalangida, and Protura which represented $29 \%$ of the total. These mesofaun a play important roles in the decomposition processes of plant residues and accelerate nutrient recycling. In addition, they are excellent indicators of soil quality.

These results are comparable to studies conducted by Culik et al. [55] and Perfecto et al. [21] who stated that collembola populations are always relatively high (50 and $67 \%$ ). Collembola have an important function in the decomposition process, carbon and nitrogen cycling in soil [114-116].

The high numbers of collembola and others were due to the contribution of litter fall residue during the annual cycle provided by the upper stratum of Inga, the middle shrub coffee stratum and the low stratum of weeds which increased the soil's ability to hold moisture, influenced the nutrient cycle and temperature, and protected the microfauna from large fluctuations in temperature and water.

\section{Conclusion}

In the upper stratum, legume trees for shade of the genus Inga (I. adenophylla and I. oerstediana) provided $9,623 \mathrm{~kg}$ (ha yr) ${ }^{-1}$ dry biomass. In the middle stratum, cultivation of coffee (Coffea arabica L.) contributed $3,032 \mathrm{~kg}(\text { ha yr })^{-1}$ of dry biomass. In the coffee-legume system, a high proportion of $\mathrm{N}$ could be derived from litterfall. Also, the fallen leaves from the leguminous trees could be the main source of organic nitrogen to the soil, and the litter produced by the coffee is low. The low stratum is influenced by mechanical weed control performed three times per year. Soil mesofaunal communities were very diverse, and further research is required to fully understand the impact of the strata on edaphic mesofaunal diversity. An $\mathrm{N}$ mass balance indicates that the coffee plants were above the critical level and that $\mathrm{N}$ additions exceeded $\mathrm{N}$ removal. 


\section{Acknowledgments}

Funding is provided by CN SARE and the South Dakota State Experiment Station.

\section{References}

[1] B. Fischersworring and R. Rosskamp, "Guia para la caficultura ecologica: café organico," in Actualizada, p. 153, GTZ. Edición Lopez, Bogotá, Colombia, 3rd edition, 2001.

[2] J. N. Wintgens, Coffee: Growing, Processing, Sustainable Production: A Guidebook for Growers, Processors, Traders, and Researchers, Wiley-VCH, Weinheim, Germany, 2009.

[3] E. W. Russell, Soil Conditions and Plant Growth, Longman Group, London, UK, 11th edition, 1988.

[4] Food and Agriculture of United Nations, "Lecture notes on the major soils of the world," 2001, http://www.fao .org/DOCREP/003/Y1899E/y1899e00.htm\#toc.

[5] F. Payán, D. L. Jones, J. Beer, and J. M. Harmand, "Soil characteristics below erythrina poeppigiana in organic and conventional Costa Rican coffee plantations," Agroforestry Systems, vol. 76, no. 1, pp. 81-93, 2009.

[6] M. Cody, W. McGill, D. Gill, J. Alegre, D. Kass, and R. Rothwell, "Patrones de liberación y distribución de nitrógeno en barbechos mejorados," Agroforestería en las Américas, vol. 7, pp. 65-67, 2000.

[7] J. Leon, "Central American and West Indian species of Inga (Leguminosae)," Annals of the Misssouri Botanical Garden, vol. 53, no. 3, pp. 265-359, 1966.

[8] J. Leon, "Inga as shade for coffee, cacao and tea: historical aspects and present day utilization," in The Genus Inga Utilization, T. D. Pennington and E. C. M. Fernandez, Eds., pp. 101-115, The Royal Botanical Gardens, Kew, UK, 1998.

[9] T. D. Pennington, "Introduction," in The Genus Inga Utilization, T. D. Pennington and E. C. M. Fernandez, Eds., pp. 159167, The Royal Botanical Gardens, Kew, UK, 1998.

[10] G. Budowski, D. C. L. Kass, and R. O. Russo, "Leguminous trees for shade," Pesquisa Agropecuaria Brasileira, vol. 19, pp. 205-222, 1984.

[11] R. G. Muschler, "Shade improves coffee quality in a suboptimal coffee-zone of Costa Rica," Agroforestry Systems, vol. 52, no. 2, article 253, pp. 131-139, 2001.

[12] R. G. Muschler, "Shade management and its effect on coffee growth and quality," in Coffee: Growing, Processing, Sustainable Production: A Guidebook for Growers, Processors, Traders, and Researchers, J. N. Wintgens, Ed., pp. 391-418, Wiley-VCH, Weinheim, Germany, 2004.

[13] N. Glover and J. Beer, "Nutrient cycling in two traditional central American agroforestry systems," Agroforestry Systems, vol. 4, no. 2, pp. 77-87, 1986.

[14] G. Galloway and J. Beer, Oportunidades Para Fomentar La Silvicultura En Cafetales En América Central, Técnica. Informe Técnico N 285, Turrialba, CATIE, Costa Rica, 1997.

[15] A. M. López-Gómez, G. Williams-Linera, and R. H. Manson, "Tree species diversity and vegetation structure in shade coffee farms in Veracruz," Agriculture, Ecosystems and Environment, vol. 124, no. 3-4, pp. 160-172, 2008.

[16] M. Van Oijin, J. Rougier, R. Smith, and P. Vaast, "Coffee agroforestry system in central America: I. A review of quantitative information on physiology and ecological processes," Agroforestry Systems, vol. 80, no. 3, pp. 341-359, 2010.
[17] P. K. Khanna, "Nutrient cycling under mixed-species tree systems in Southeast Asia," Agroforestry Systems, vol. 38, no. 1-3, pp. 99-120, 1997.

[18] B. B. Lin, "The role of agroforestry in reducing water loss through soil evaporation and crop transpiration in coffee agroecosystems," Agricultural and Forest Meteorology, vol. 150, no. 4, pp. 510-518, 2010.

[19] P. Siles, J. M. Harmand, and P. Vaast, "Effects of Inga densiflora on the microclimate of coffee (Coffea arabica L.) and overall biomass under optimal growing conditions in Costa Rica," Agroforestry Systems, vol. 78, no. 3, pp. 269-286, 2010.

[20] I. Perfecto, R. A. Rice, R. Greenberg, and M. E. Van Der Voort, "Shade coffee: a disappearing refuge for biodiversity," BioScience, vol. 46, no. 8, pp. 598-608, 1996.

[21] I. Perfecto, J. Vandermeer, P. Hanson, and V. Cartín, "Arthropod biodiversity loss and the transformation of a tropical agro-ecosystem," Biodiversity and Conservation, vol. 6, no. 7, pp. 935-945, 1997.

[22] V. E. Méndez, E. N. Shapiro, and G. S. Gilbert, "Cooperative management and its effects on shade tree diversity, soil properties and ecosystem services of coffee plantations in Western El Salvador," Agroforestry Systems, vol. 76, no. 1, pp. 111-126, 2009.

[23] J. P. Roskoski, J. Montano, C. Van Kessel, and G. Castilleja, "Nitrogen fixation by tropical woody legumes: potential source of soil enrichment," in Biological Nitrogen Fixation Technology for Tropical Agriculture, pp. 447-455, Centro International de Agricultura Tropical (CIAT), 1982.

[24] J. P. Roskoski, "Nitrogen fixation in a Mexican coffee plantation," Plant and Soil, vol. 67, no. 1-3, pp. 283-291, 1982.

[25] G. Escalante, R. Herrera, and J. Aranguren, "Nitrogen fixation in shade trees (Erythrina poeppigiana) in cacao plantations in North Venezuela," Pesquisa Agropecuaria Brasileira, vol. 19, pp. 223-230, 1984.

[26] Y. R. Dommergues, H. G. Diem, D. L. Gauthier, B. L. Dreyfus, and F. Cornet, "Nitrogen-fixing trees in the tropics: potentials and limitations," in Advances in Nitrogen Fixation Research, C. Veeger and W. E. Newton, Eds., pp. 7-13, Nijhoff, Wageningen, Netherlands, 1984.

[27] A. Lawrence, T. D. Pennington, M. R. Hands, and R. A. Zuniga, "Inga: high diversity in the neo-tropics," in Nitrogen Fixing Trees for Acid Soils, D. O. Evans and L. T. Szott, Eds., pp. 130-141, Winrock International, 1995.

[28] J. I. Sprent, "Legume trees and shrubs in the tropics, $\mathrm{N}_{2}$ fixation in perspective," Soil Biology \& Biochemistry, vol. 27, no. 4-5, pp. 401-407, 1995.

[29] L. Frioni, R. Dodera, D. Malatés, and I. Irigoyen, "An assessment of nitrogen fixation capability of leguminous trees in Uruguay," Applied Soil Ecology, vol. 7, no. 3, pp. 271279, 1998.

[30] E. C. M. Fernandes, "Nodulation and nitrogen fixation in the genus Inga," in The Genus Inga Utilization, T. D. Pennington and E. C. M. Fernandes, Eds., pp. 41-52, The Royal Botantical Gardens, Kew, UK, 1998.

[31] J. I. Sprent and R. Parsons, "Nitrogen fixation in legume and non-legume trees," Field Crops Research, vol. 65, no. 2-3, pp. 183-196, 2000.

[32] L. Soto-Pinto, I. Perfecto, J. Castillo-Hernandez, and J. Caballero-Nieto, "Shade effect on coffee production at the Northern Tzeltal zone of the state of Chiapas, Mexico," 
Agriculture, Ecosystems \& Environment, vol. 80, no. 1-2, pp. 61-69, 2000.

[33] K. E. Giller, "Agroforestry: $\mathrm{N}_{2}$-fixing trees in integrated agriculture," in Nitrogen Fixation in Tropical Cropping Systems, pp. 222-250, CABI Publishing, Oxfordshire, UK, 2001.

[34] J. M. Grossman, C. Sheaffer, D. Wyse, and P. H. Graham, "Characterization of slow-growing root nodule bacteria from Inga oerstediana in organic coffee agroecosystems in Chiapas, Mexico," Applied Soil Ecology, vol. 29, no. 3, pp. 236251, 2005.

[35] J. M. Grossman, C. Sheaffer, D. Wyse, B. Bucciarelli, C. Vance, and P. H. Graham, "An assessment of nodulation and nitrogen fixation in inoculated Inga oerstediana, a nitrogenfixing tree shading organically grown coffee in Chiapas, Mexico," Soil Biology \& Biochemistry, vol. 38, no. 4, pp. 769784, 2006.

[36] L. I. Babbar and D. R. Zak, "Nitrogen cycling in coffee agroecosystems: net $\mathrm{N}$ mineralization and nitrification in the presence and absence of shade trees," Agriculture, Ecosystems and Environment, vol. 48, no. 2, pp. 107-113, 1994.

[37] J. Aranguren, G. Escalante, and R. Herrera, "Nitrogen cycle of tropical perennial crops under shade trees," Plant and Soil, vol. 67, no. 1-3, pp. 247-258, 1982.

[38] E. Bornemisza, "Nitrogen cycling in coffee plantations," Plant and Soil, vol. 67, no. 1-3, pp. 241-246, 1982.

[39] C. Pinkert, Nutrient and Quality Analysis of Coffee Cherries in Huong Hoa District, Vietnam, Plant Research International, Wageningen, The Netherlands, 2004, http://edepot.wur.nl/38916.

[40] R. Medina, A. González, and L. Rodríguez, "Coffee trees litter fall and potential macroelements in two ecosystems," Facultad de Ciencias agronómicas, Investigación Agrícola, Universidad de Chile, 2000, http:// www.agronomia.uchile.cl/investigacion/publicaciones/investigacionagricola/20/index.htm.

[41] R. G. Barber and F. Navarro, "The rehabilitation of degraded soils in Eastern Bolivia by subsoiling and the incorporation of cover crops," Land Degradation \& Development, vol. 5, no. 4, pp. 247-259, 1994.

[42] P. Moguel and V. M. Toledo, "Biodiversity conservation in traditional coffee systems of Mexico," Conservation Biology, vol. 13, no. 1, pp. 11-21, 1999.

[43] O. Polyakova and N. Billor, "Impact of deciduous tree species on litterfall quality, decomposition rates and nutrient circulation in pine stands," Forest Ecology and Management, vol. 253, no. 1-3, pp. 11-18, 2007.

[44] Y. Sánchez-de León, E. De Melo, G. Soto, J. JohnsonMaynard, and J. Lugo-Pérez, "Earthworm populations, microbial biomass and coffee production in different experimental agroforestry management systems in Costa Rica," Caribbean Journal of Science, vol. 42, no. 3, pp. 397-409, 2006.

[45] K. Hairiah, H. Sulistyani, D. Suprayogo, P. Purnomosidhi, R. H. Widodo, and M. V. Noordwijk, "Litter layer residence time in forest and coffee agroforestry systems in Sumberjaya, West Lampung," Forest Ecology and Management, vol. 224, no. 1-2, pp. 45-57, 2006.

[46] W. T. Lanini, "Use of perennial cover crops to suppress weeds in Nicaraguan coffee orchards," International Journal of Pest Management, vol. 41, no. 4, pp. 185-194, 1995.

[47] D. Nestel and M. A. Altieri, "The weed community of Mexican coffee agroecosystems: effect of management upon plant biomass and species composition," Acta Oecologica, vol. 13, no. 6, pp. 715-726, 1992.
[48] M. Schawe, S. Glatzel, and G. Gerold, "Soil development along an altitudinal transect in a Bolivian tropical montane rainforest: podzolization vs. hydromorphy," Catena, vol. 69, no. 2, pp. 83-90, 2007.

[49] G. Gerold, M. Schawe, and K. Bach, "Hydrometeorologic, pedologic and vegetation patterns along an elevational transect in the montane forest of the Bolivian Yungas," Die Erde, vol. 139, no. 1-2, pp. 141-168, 2008.

[50] Soil Survey Staff, Keys to Soil Taxonomy, United States Department of Agriculture, Natural Resources Conservation Service, Washington, DC, USA, 11th edition, 2010.

[51] E. V. J. Tanner, P. M. Vltousek, and E. Cuevas, "Experimental investigation of nutrient limitation of forest growth on wet tropical mountains," Ecology, vol. 79, no. 1, pp. 10-22, 1998.

[52] J. W. Hughes, T. J. Fahey, and B. Browne, "A better seed and litter trap," Canadian Journal of Forest Research, vol. 17, no. 12, pp. 1623-1624, 1987.

[53] R. Kershnar and F. Montagnini, "Leaf litter decomposition, litterfall, and effects of leaf mulches from mixed and monospecific plantations in Costa Rica," Journal of Sustainable Forestry, vol. 7, no. 3-4, pp. 95-118, 1998.

[54] H. Schillhammer, "Instruction manual on collecting, preserving and preparing beetles (coleoptera)," Natural History Museum, Vienna, Austria, 2001.

[55] M. P. Culik, D. S. Martins, and J. A. Ventura, "Collembola (Arthropoda: Hexapoda) communities in the soil of papaya orchards managed with conventional and integrated production in Espirito Santo, Brazil," Biota Neotropica, vol. 6, no. 2, 2006.

[56] A. Anu, T. K. Sabu, and P. J. Vineesh, "Seasonality of litter insects and relationship with rainfall in a wet evergreen forest in south Western Ghats," Journal of Insect Science, vol. 9, article 46, pp. 1-10, 2009, http://www.insectscience.org/9.46/i1536-2442-9-46.pdf.

[57] R. C. Littel, G. A. Milliken, W. W. Stroup, and R. D. Wolfinger, SAS for Mixed Models, SAS Institute, Cary, NC, USA, 2000.

[58] R. C. Littel, W. W. Stroup, and R. J. Freund, SAS for Linear Models, SAS Institute, Cary, NC, USA, 4th edition, 2002.

[59] G. A. Milliken and D. E. Johnson, Analysis of Messy Data Volume 1: Designed Experiments, Chapman and Hall, New York, NY, USA, 1997.

[60] R. Bidwell, “Fisiología vegetal," Editorial AGT, México D. F., pp. 587-590,1993.

[61] L. S. Santiago and S. S. Mulkey, "Leaf productivity along a precipitation gradient in lowland Panama: patterns from leaf to ecosystem," Structure and Function, vol. 19, no. 3, pp. 349356, 2005.

[62] B. Fischersworring, Guía Para la Caficultura Ecológica, Editorial López, Ministerio de Cooperación Económico y Desarrollo (BMZ) de la República Federal de Alemania, 2001.

[63] E. Winston, J. Op de Laak, T. Marsh, H. Lempke, and K. Chapman, "Arabica coffee manual for Lao-PDR," 2005, http://www.fao.org/docrep/008/ae939e/ae939e00.htm\# Contents.

[64] B. B. Lin, "Microclimate efffects on flowering success in coffee agroforestry systems," American-Eurasian Journal of Agricultural and Environmental Sciences, vol. 3, pp. 148-152, 2008.

[65] C. R. Elevitch, T. Idol, J. B. Friday, C. Lepczyk, V. E. Smith, and S. C. Nelson, Shade-Grown Coffee in Hawai' $i$ : Results of a Twelve Farm Study in Kona, Permanent Agriculture Resources, Honolulu, Hawaii, USA, 2009, http://agroforestry.net/caf/. 
[66] J. P. Tewari, L. M. Browne, and W. A. Ayer, "The American leaf spot of coffee," University of Alberta Agriculture and Forestry Bulletin, 1984.

[67] S. C. Nelson, "Cercospora leaf spot and berry blotch of coffee," College of Tropical Agriculture and Human Resources, University of Hawai'i at Manoa, 2008, http://www.ctahr.hawaii.edu/oc/freepubs/pdf/PD-41.pdf.

[68] D. V. Rao and J. P. Tewari, "Suppression of the symptoms of American leaf spot of coffee with calcium hydroxide," Plant Diseases, vol. 72, no. 8, pp. 688-690, 1988.

[69] J. C. Martinez-Sanchez, The role of organic production in biodiversity conservation in shade coffee plantations, Ph.D. thesis, University of Washington, 2008.

[70] J. M. Grossman, "Exploring farmer knowledge of soil processes in organic coffee systems of Chiapas, Mexico," Geoderma, vol. 111, no. 3-4, pp. 267-287, 2003.

[71] F. X. Susilo, A. M. Neutel, M. van Noordwijk, K. Hairiah, G. Brown, and M. J. Swift, "Soil biodiversity and food webs," in Below-Ground Interactions in Tropical Agroecosystems: Concepts and Models with Multiple Plant Communities, M. Van Noordwijk, G. Cadisch, and C. K. Ong, Eds., CABI Publishing, Cambridge, Mass, USA, 2004.

[72] M. Altieri, "The ecological role of biodiversity in agroecosystems," Agriculture, Ecosystems and Environment, vol. 74, no. 1-3, pp. 19-31, 1999.

[73] T. E. Wood, D. Lawrence, D. A. Clark, and R. L. Chazdon, "Rain forest nutrient cycling and productivity in response to large-scale litter manipulation," Ecological Society of America, vol. 90, no. 1, pp. 109-121, 2009.

[74] International Coffee Organization, "Ecology," 2008, http:// www.ico.org/ecology.asp.

[75] D. Calentano, R. A. Zahawi, B. Finegan, R. Ostertag, R. J. Cole, and K. D. Holl, "Litterfall dynamics under different tropical forest restoration strategies in Costa Rica," Biotropica, vol. 43, no. 3, pp. 279-287, 2010.

[76] J. Chave, D. Navarrete, S. Almeida et al., "Regional and seasonal patterns of litterfall in tropical South America," Biogeosciences, vol. 7, pp. 43-55, 2010.

[77] A. Youkhana and T. Idol, "Tree pruning mulch increases soil $\mathrm{C}$ and $\mathrm{N}$ in a shaded coffee agroecosystem in Hawaii," Soil Biology and Biochemistry, vol. 41, no. 12, pp. 2527-2534, 2009.

[78] S. Davidson, "Shade coffee agro-ecosystems in Mexico: a synopsis of the environmental services and socio-economic considerations," Journal of Sustainable Forestry, vol. 21, no. 1, pp. 81-95, 2005.

[79] V. H. Arana-Meza, Nitrogen dynamics in an organic management of coffee (Coffea arabica L.) associated with poró (erythrina poeppigiana (walpers) O.F cook), M.S. thesis, CATIE, Turrialba, CR, 2003.

[80] J. Beer, C. Harvey, M. Ibrahim, J. M. Harmand, E. Somarriba, and F. Jiménez, "Servicios ambientales de los sistemas agroforestales," Agroforestería en las Américas, vol. 10, no. 37, pp. 80-87, 2003.

[81] Organismo Internacional Regional de Sanidad Agropecuaria (OIRSA), 2000, http://www.oirsa.org/aplicaciones/subidoarchivos/BibliotecaVirtual/MANUALCAFEORGANICO.pdf.

[82] J. F. Sánchez, R. A. Moreno, and F. Muñoz, "Erythrina fusca: un árbol leguminosa de la costa norte de Colombia con potencial agroforestal," in Erythrina in the New and Old Worlds, S. B. Westley and M. H. Powell, Eds., pp. 5561, Niagara Frontier Transportation Authority, Honolulu, Hawaii, USA, 1993.
[83] L. Alpizar, H. W. Fassbender, and J. Heuveldop, "Estudio de sistemas agroforestales en el experimento central del CATIE, Turrialba, 1. Determinación de biomasa y acumulación de reservas nutritivas (N, P, K, Ca, Mg)," Turrialba, 1983.

[84] M. A. Rutherford and N. Phiri, Pests and Diseases of Coffee in Eastern Africa: A Technical and Advisory Manual, CAB International, Wallingford, UK, 2006.

[85] J. M. Njoroge, "Agronomic and processing factors affecting coffee quality," Outlook on Agriculture, vol. 27, no. 3, pp. 163166, 1998.

[86] P. Mazzafera, "Mineral nutrition and caffeine content in coffee leaves,” Bragantia, vol. 58, no. 2, pp. 387-391, 1999.

[87] CRT Coffee Research Institute, "Coffee quality and environmental conditions," Coffee Research Newsletter, vol. 1, no. 3, pp. 4-6, 2001.

[88] J. Snoeck and Ch. Lambot, "Crop maintenance," in Coffee: Growing, Processing, Sustainable Production, A guide book for Growers, Processors, Traders and Researchers, J. N. Wintgens, Ed., pp. 246-323, Wiley-VCH, Weinheim, Germany, 2005.

[89] F. Decazy, J. Avelino, B. Guyot, J. J. Perriot, C. Pineda, and C. Cilas, "Quality of different Honduran coffees in relation to several environments," Journal of Food Science, vol. 68, no. 7, pp. 2356-2361, 2003.

[90] D. Snoeck, F. Zapata, and A. M. Domenach, "Isotopic evidence of the transfer of nitrogen fixed by legumes to coffee trees," Biotechnology, Agronomy, Society and Environment, vol. 4, pp. 95-100, 2000.

[91] P. Vaast, R. Van Kanten, P. Siles et al., "Shade: a key factor for coffee sustainability and quality," in Proceedings of the 20th International Congress on Coffee Science, pp. 887-896, Bangalore, India, October 2004.

[92] P. Vaast, B. Bertrand, J. J. Perriot, B. Guyot, and M. Génard, "Fruit thinning and shade improve bean characteristics and beverage quality of coffee (Coffea arabica L.) under optimal conditions," Journal of the Science of Food and Agriculture, vol. 86, no. 2, pp. 197-204, 2006.

[93] A. Albertin and P. K. R. Nair, "Farmers' perspectives on the role of shade trees in coffee production systems: an assessment from the Nicoya Peninsula, Costa Rica," Journal of Human Ecology, vol. 32, no. 4, pp. 443-463, 2004.

[94] A. Titus and G. N. Pereira, "Nitrogen economy inside coffee plantations," 2008, http://www.ineedcoffee.com/06/ nitrogen/.

[95] L. Ukonmaanaho, P. Merilä, P. Nöjd, and T. M. Nieminen, "Litterfall production and nutrient return to the forest floor in scots pine and Norway spruce stands in Finland," Boreal Environment Research, vol. 13, pp. 67-91, 2008.

[96] E. A. Veasey, A. A. Ghisi, M. A. Cardelli, and D. A. Beisman, "Evaluation of shrub and tree legumes in Brazil," in Nitrogen Fixing Tree Research Reports, vol. 13, pp. 1-5, 1995.

[97] F. Tilki and R. F. Fisher, "Tropical leguminous species for acid soils: studies on plant form and growth in Costa Rica," Forest Ecology and Management, vol. 108, no. 3, pp. 175-192, 1998.

[98] M. dos S. Freire Ricci, B. J. Rodrigues Alves, S. Cordeiro de Miranda, and F. Freire de Oliveira, "Growth rate and nutritional status of an organic coffee cropping system," Scientia Agricola, vol. 62, no. 2, pp. 138-144, 2005.

[99] C. A. Palm and P. A. Sanchez, "Decomposition and nutrient release patterns of the leaves of three tropical legumes," Biotropica, vol. 22, no. 4, pp. 330-338, 1990.

[100] C. A. Palm and P. A. Sanchez, "Nitrogen release from the leaves of some tropical legumes as affected by their lignin and 
polyphenolic contents," Soil Biology and Biochemistry, vol. 23, no. 1, pp. 83-88, 1991.

[101] Z. A. Li, S. L. Peng, D. J. Rae, and G. Y. Zhou, "Litter decomposition and nitrogen mineralization of soils in subtropical plantation forests of southern China, with special attention to comparisons between legumes and non-legumes," Plant and Soil, vol. 229, no. 1, pp. 105-116, 2001.

[102] L. Y. K. Peeters, L. Soto-Pinto, H. Perales, G. Montoya, and M. Ishiki, "Coffee production, timber, and firewood in traditional and Inga-shaded plantations in Southern Mexico," Agriculture, Ecosystems and Environment, vol. 95, no. 2-3, pp. 481-493, 2003.

[103] J. Beer, "Litter production and nutrient cycling in coffee (Coffea arabica) or cacao (Theobroma cacao) plantations with shade trees," Agroforestry Systems, vol. 7, no. 2, pp. 103-114, 1988.

[104] E. Malavolta, "Nutricao mineral e adubacao do cafeeiro," Associacao Brasleira para Pesquisa da Potassa e do Fosfato (Piracicaba) and Editora Agronomica Ceres Ltda (Sao Paulo), 1990.

[105] G. Hart, "A nutritional survey of coffea arabica plantations in New Guinea," Research Bulletin No. 5. Department of Agriculture, Stock and Fisheries, Port Moresby, 1969.

[106] A. V. Chaves and E. Molina, "Extraccion de Nitrogeno en dos cultivares de cafe en Costa Rica," in Proceedings of the Simposio Latinoamericano de Caficultura XIX, pp. 155-165, Memorias, San Jose, Costa Rica, October 2000.

[107] P. Harding, "The PNG coffee handbook," Coffee Research Institute (CRI), Kainantu, Papua New Guinea, 1991.

[108] Y. Romero-Alvarado, L. Soto-Pinto, L. García-Barrios, and J. F. Barrera-Gaytán, "Coffee yields and soil nutrients under the shades of Inga sp. vs. multiple species in Chiapas, Mexico," Agroforestry Systems, vol. 54, no. 3, pp. 215-224, 2002.

[109] M. H. Beare, M. Vikram, G. Tian, and S. C. Srivastava, "Agricultural intensification, soil biodiversity and agroecosystem function in the tropics: the role of decomposer biota," Applied Soil Ecology, vol. 6, no. 1, pp. 87-108, 1997.

[110] E. Franklin and J. W. de Morais, "Soil mesofauna in central Amazon," in Soil Biodiversity in Amazonian and other Brazilian Ecosystems, F. M. S. Moreira, J. O. Siqueira, and L. Brussaard, Eds., pp. 142-162, CABI Publishing, Oxfordshire, UK, 2006.

[111] A. Karyanto, C. Rabmadi, E. Franklin, F. X. Susilo, and J. W. de Morais, "Soil collembola, acari and other mesofaunathe berlese method," in A Handbook of Tropical Soil Biology: Sampling \& Characterization of Below-Ground Biodiversity, F. M. S. Moreira, E. J. Huising, and D. E. Bignell, Eds., pp. 8595, Earthsean Publishing for a Sustainables Future, London, UK, 2008.

[112] F. M. S. Moreira, E. J. Huising, and D. E. Bignell, Eds., A Handbook of Tropical Soil Biology: Sampling and Characterization of Below-ground Biodiversity, Earthscan, London, UK, 2008.

[113] J. F. Ponge, S. Gillet, F. Dubs et al., "Collembolan communities as bioindicators of land use intensification," Soil Biology and Biochemistry, vol. 35, no. 6, pp. 813-826, 2003.

[114] J. Filser, "The role of collembola in carbon and nitrogen cycling in soil," Pedobiologia, vol. 46, no. 3-4, pp. 234-245, 2002.

[115] S. Kaneda and N. Kaneko, "Collembolans feeding on soil affect carbon and nitrogen mineralization by their influence on microbial and nematode activities," Biology and Fertility of Soils, vol. 44, no. 3, pp. 435-442, 2008.
[116] P. Kardol, W. N. Reynolds, R. J. Norby, and A. T. Classen, "Climate change effects on soil microarthropod abundance and community structure," Applied Soil Ecology, vol. 47, no. 1, pp. 37-44, 2011. 


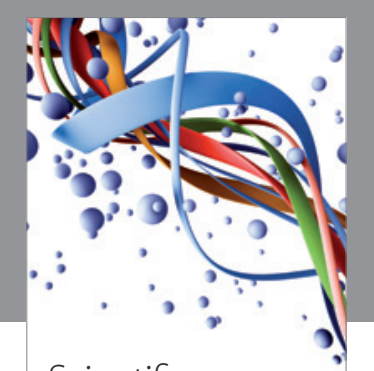

Scientifica
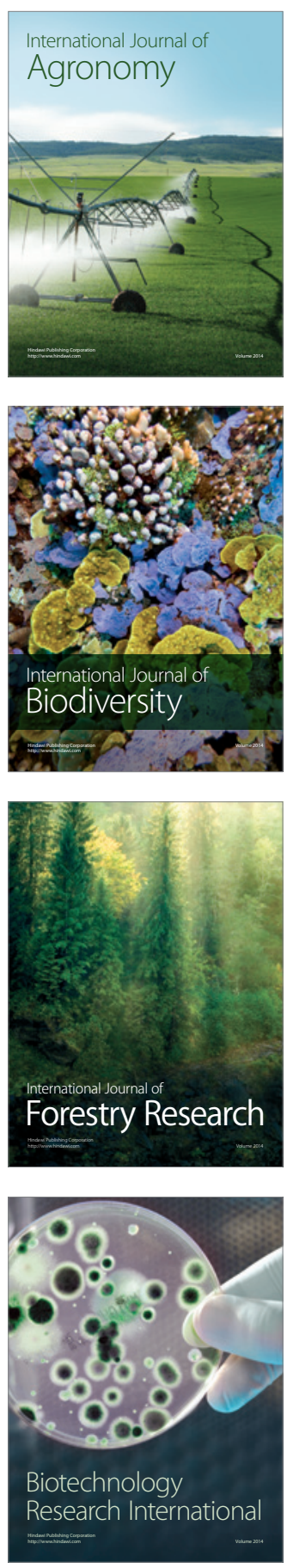
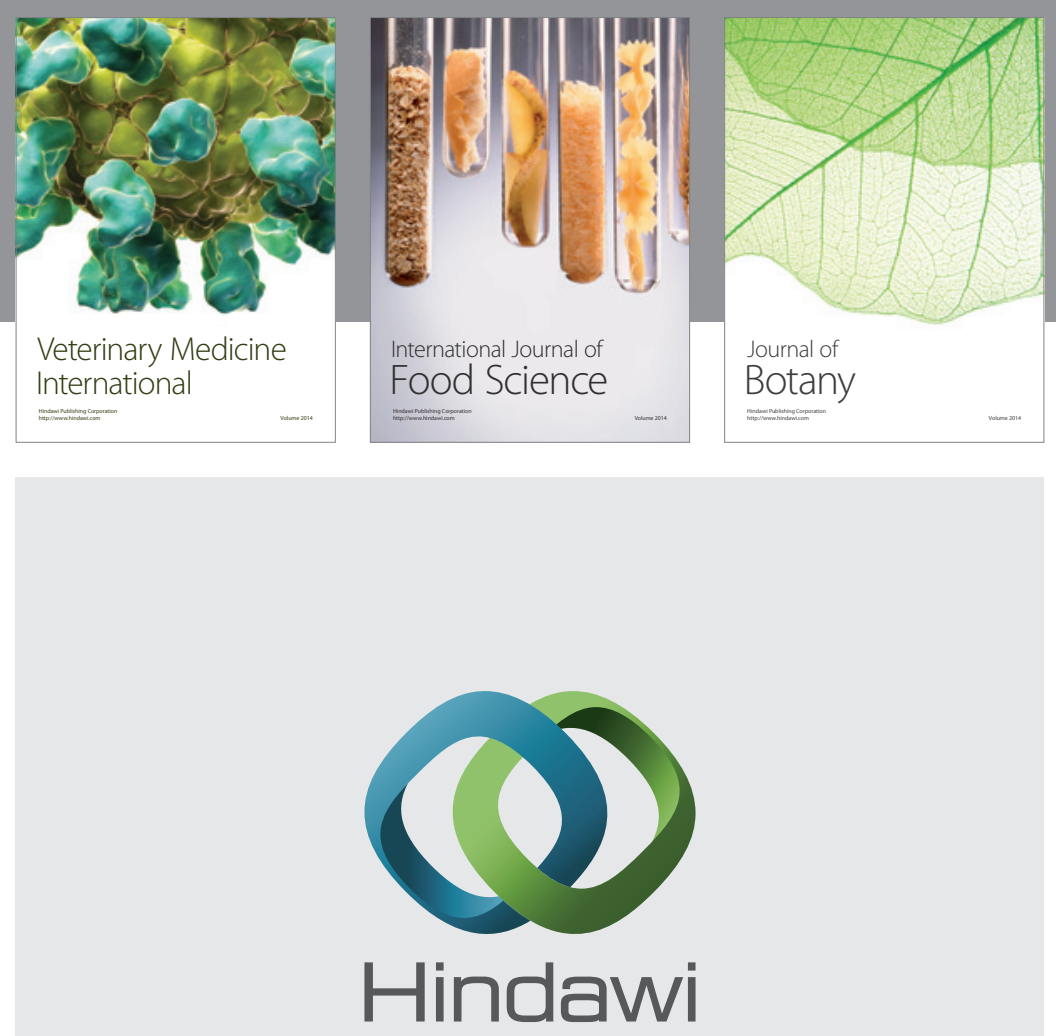

Submit your manuscripts at

http://www.hindawi.com
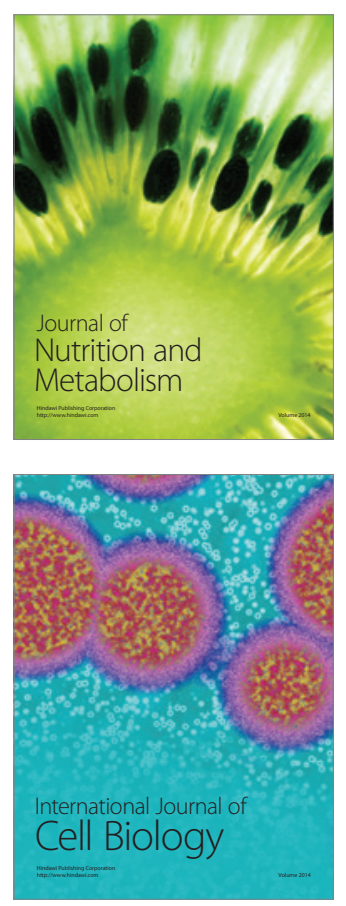
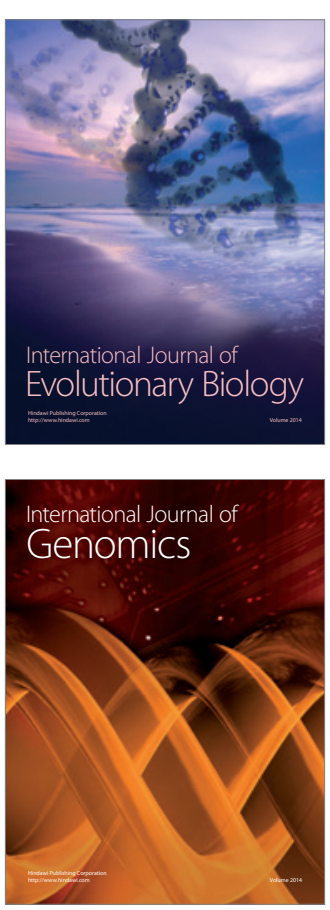
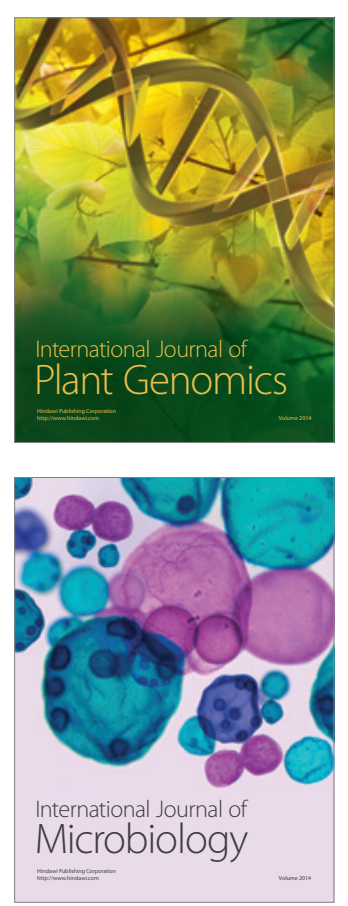

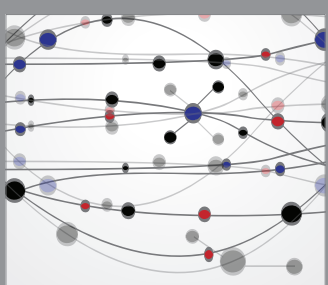

The Scientific World Journal
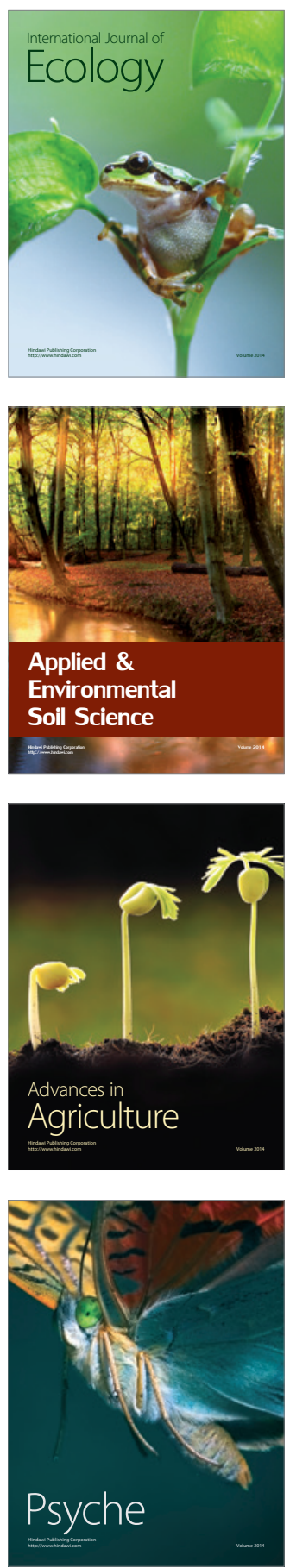